\title{
CARPOLOGY AND PHERMATOLOGY OF GOMORTEGA (GOMORTEGACEAE): SYSTEMATIC AND EVOLUTIONARY IMPLICATIONS
}

\author{
Alexander B. DOWELD
}

\begin{abstract}
Carpology and phermatology of Gomortega (Gomortegaceae): Systematic and evolutionary implications. The anatomy and morphology of the fruits and seeds of Gomortega keule (Mol.) Baill., comprising a monotypic genus in the monogeneric family Gomortegaceae Reiche, have been studied in an effort to clarify its systematic position. The fruits are fleshy inferior coenocarpous drupines, giving the appearance (due to the lateral concrescence of spirally arranged 2-6 carpels) of mostly 2-3-locular or rarely pseudomonomerous syncarpous fruit. Seeds are flattened, exarillate, abundantly albuminous with a small embryo, originate from hemianatropous crassinucellate, bitegmic ovules. The seed coat is endotestalendotegmic; the endotesta, only testal layer preserved in the mature spermoderm, is of tracheotestal type, having peculiar numerous spiral or annular projections penetrating into the cell cavities. Evidence, mainly from seed anatomy and morphology, emphasizes phylogenetic unity of Gomortega having aberrant inferior fruits with Monimiaceae s.l. or more correctly, a group of the families Monimiaceae s. str., Amborellaceae, Hortoniaceae, Siparunaceae, and Atherospermataceae. Gomortegaceae especially have common roots with Atherospermataceae, sharing similar tracheotestal endotestal type of seed coats, albuminous seeds with small embryos, similar chromosome number, morphology of sieve-element plastids, palynomorphology, xylem anatomy, and distinctive staminodial appendages and valvular dehiscence of anthers. With the addition of more data on the fruit and seed anatomy and morphology of Atherospermataceae, the interrelationships of Gomortega and Atherospermataceae would be defined more precisely.
\end{abstract}

Key words. Gomortega keule (Mol.) Baill., keule (queule), carpology, pericarp, seed anatomy and evolution, Gomortegaceae, Atherospermataceae, Monimiaceae, Lauraceae, Magnoliidae, Ranunculidae, Caryophyllidae, Hamamelididae, Rosidae, Dilleniidae.

RESUMEN. Carpología y morfología de la cubierta de la semilla de Gomortega (Gomortegaceae): implicaciones sistemáticas y evolutivas. En un esfuerzo de clarificar la posición sistemática del género Gomortega, en el presente trabajo se estudia la morfología y anatomía de los frutos y semillas de Gomortega keule (Mol.) Baill., perteneciente al género monotípico anteriormente citado, de la monogenérica familia Gomortegaceae Reiche. Los frutos son drupas cenocárpicas carnosas, que ofrecen la apariencia de frutos sincárpicos bi- o triloculares, o más raramente uniloculares, debido a la concrescencia lateral de los $2-6$ carpelos que lo componen y que se encuentran espiraladamente dispuestos. Las semillas son aplanadas, desprovistas de arilo, con albúmen abundante y embrión pequeño, originadas a partir de primordios seminales bitégmicos, anátropos y crasinucelados. La cubierta de la semilla es endotestal-endotégmica; la endotesta (sólo la base testal se preservó en la espermodermis madura) es de tipo traqueotestal, presentando la peculiaridad de poseer mumerosas proyecciones anulares o espiraladas que penetran en las cavidades celulares. Las evidencias encontradas, fundamentalmente en base a la morfología y anatomía de las semillas, apoyan la relación filogenética existente entre Gomortega, con frutos ínferos aberrates, y Monimiaceae s.l. o, más correctamente, con el grupo de las familias Monimiaceae s. str., Amborellaceae, Hortoniaceae, Siparubaceae y Atherospermataceae, que comparten un tipo similar de cubierta seminal 
endotestal y traqueotestal, semillas albuminadas, con embrión pequeño, similar número de cromosomas, morfologia de los plastidios de los elementos cribosos del floema, morfología polínica, anatomía del xilema, los apéndices de los estaminodios y la dehiscencia valvar de las anteras. Con la aportación de una mayor cantidad de datos sobre la morfología y anatomía de los frutos y semillas de Atherospermataceae, las interrelaciones existentes entre Gomortega y Atherospermataceae podrían ser definidas de manera más precisa.

Palagras clave. Gomortega keule (Mol.) Baill., keule (queule), carpologÍa, pericarpo, anatomia seminal y evolucion, Gomortegaceae, Atherospermataceae, Monimiaceae, Lauraceae, Magnoliidae, Ranunculidae, Caryophyllidae, Hamamelididae, Rosidae, Dilleniidae

\section{INTRODUCTION}

The arborescent Chilean plants Queule (Keule) are currently well-known in systematic botany as Gomortega keule (Mol.) Baill., that comprises a distinct monotypic family Gomortegaceae Reiche. They were at first time described by Molina (1782) under the name of Lucuma keule Mol. Since the genus was turned out to be composed of unrelated members, the name has been rejected in a favour of published later Gomortega nitida Ruiz \& Pav. (Ruiz López \& Pavón, 1794), and then corrected according to the established rules of botanical nomenclature by Baillon (1867/1869) on $G$. keule (Mol.) Baill. (cf. Johnston, 1924; Espinosa Bustos, 1948; Gunckel, 1972). In old botanical literature of XIX century these plants were often, but invalidly named as Adenostemum nitidum (Ruiz \& Pav.) Pers., since Persoon (1805) renamed the genus, treating the name Gomortega as invalid later nomen to Ortega L., which has been already established by Linnè (1753) to honour the name of Casimir Gómez-Ortega, professor of the Royal Botanical Garden in Madrid. Later Molina (1810) proposed once more invalid name for these plants: Keulia chilensis Mol.

Likewise the confused nomenclature of the species, the taxonomic position was also indefinite and complicated. Ruiz López \& Pavón (1794) and Persoon (1805) placed Gomortega into artificial Linnaean 10th class Decandria monogynia together with Cercis L., Bauhinia L., Parkinsonia L., Caesalpinia L.,
Cassia L., Gaertnera L., Zygophyllum L., Monotropa L., Pyrola L., Styrax L., and even Rhododendron L. Endlicher (1836/1840) synonymized Gomortega with Peumus Nees (now in Monimiaceae Juss. s.l.), which he included in Cryptocarya $\mathrm{R}$. Br. (Lauraceae Juss.). Lindley (1853) accepted this taxonomic re-arrangement. Philippi (1864/1865) refuted phylogenetic relationships of Gomortega with Lauraceae, emphasizing occurrence of mostly trimerous inferior ovary and abundant endosperm in seeds. Later Philippi (1868) supposed a monimiaceous affinity for a doubtful genus, regarding it as a connecting link between Lauraceae and Monimiaceae. Mez (1888) agreed with Philippi (1864/1865, 1865, 1868) and transferred Gomortega into Monimiaceae. But Bentham \& Hooker (1883) suggested a quite another, curious affinity to Euphorbiaceae Juss., seeing a resemblance in trimerous construction of gynoecia. Nevertheless, Reiche (1896) regarded this resemblance as superficial and therefore erected a distinct family Gomortegaceae, emphasizing thereby its differences with both closely allied Lauraceae and Monimiaceae.

Hallier (1912) rejected a distinct family for Gomortega and included it into Monimiaceae [as did Mez (1888)], connecting with Calycanthaceae Lindl., Lauraceae, and Chloranthaceae R. Br. ex Lindl. Later Swamy (1953) also thought it possible to reveal some close phylogenetic relationships with Chloranthaceae. Bessey (1915) and Engler \& Gilg (Engler, 1919), representatives of two 
antagonistic approaches to the classification of flowering plants, agreed to place distinct family Gomortegaceae near mostly Myristicaceae R. Br.: Bessey placed it in Ranales between Lactoridaceae Engl. and Myristicaceae, in a similar way Engler \& Gilg positioned Gomortegaceae between Myristicaceae and Monimiaceae in special suborder Magnoliineae. Hutchinson (1926) included Gomortegaceae into Laurales along with Monimiaceae, Lauraceae, Hernandiaceae Blume, and again Myristicaceae.

Garratt (1934), studying wood anatomy of Gomortega, suggested an affinity with atherospermataceous genera Atherosperma Labill., Daphnandra Benth., Doryphora Endl., and Laurelia Juss. of Monimiaceae s.l. (= Atherospermataceae $\mathrm{R}$. Br.). These close phylogenetic relationships have been later confirmed by chromosome analysis (Goldblatt, 1976) and morphology of sieve-element plastids (Behnke, 1988). Nevertheless, Metcalfe \& Chalk (1950), on the basis of wood anatomical characters, agreed with general lauralean affinity, but pointed out to a possible relationship of Gomortega to Canellaceae Mart. Later Stern (1955) in a thorough study of xylem structure rejected any idea of canellaceous relationships and suggested that "most likely Gomortegaceae is closely allied to Monimiaceae through a Hortonia-like forebear with valvate anthers'. This point of view is accepted in most modern systems of angiosperms (Dahlgren, 1989; Cronquist, 1992; Thorne, 1992; Takhtajan, 1997). Nonetheless, Gottwald (1977) on the basis of again xylem characteristics placed Gomortegaceae in his 'Hamamelidal-Dillenial' (!) Group within magnolialean families.

There are no record of carpological descriptions of Gomortega, except for some general dissections of the fruits presented by Ruiz López \& Pavón (1794) and Reiche's (1896) discovery of the spiral arrangement of carpels in syncarpous gynoecium. The same is true for seeds (Corner, 1976; Fedotova, 1988) except for corrections of Reiche (1896) of some previous erroneous descriptions of embryo as small (Philippi, 1868); the spermoderm is till described only as 'thin and brittle'. Recently Endress \& Igersheim (1997) described several additional details of the general morphology and anatomy of ovules and carpels constituting the inferior ovary of Gomortega. Here we attempt to elucidate the phylogenetic relationships of Gomortegaceae using the additional carpological and phermatological features of Gomortega.

\section{MATERIALS AND METHODS}

Mature fruits containing ripe seeds of Gomortega keule (Mol.) Baill. were obtained from the Herbario, Departamento de

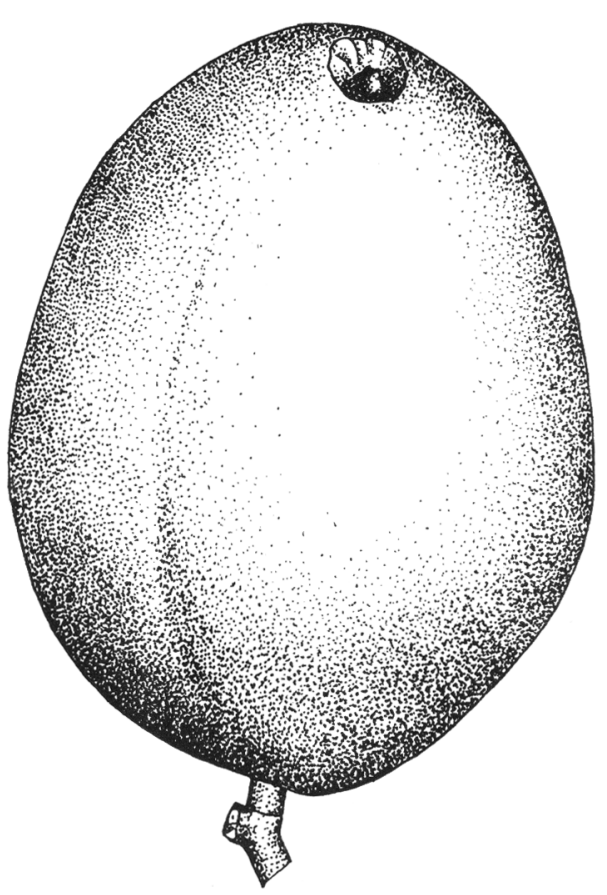

Figure 1. General view of the mature fruit of Gomortega keule (Mol.) Baill., x 15. 

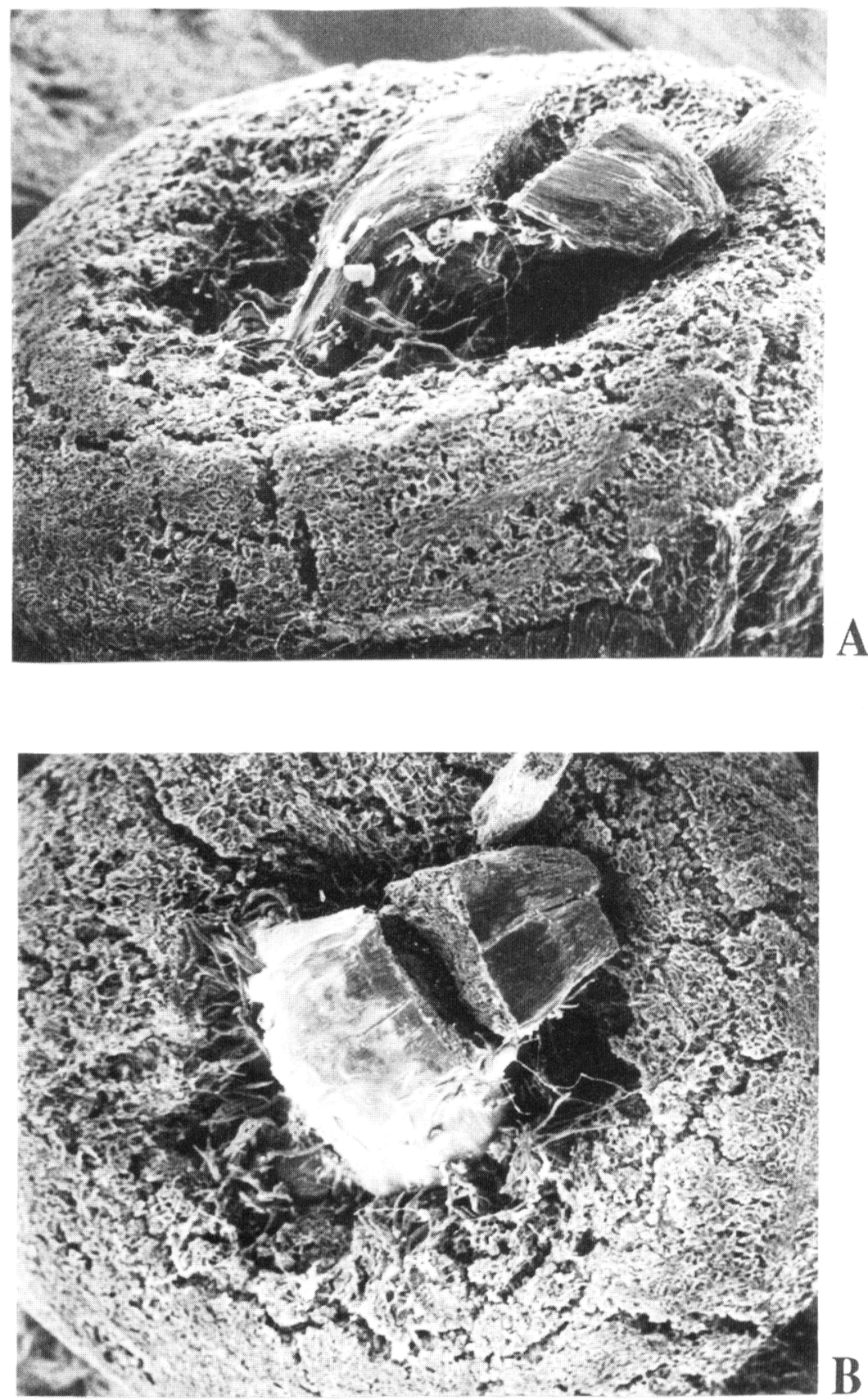

Figure 2. SEM micrographs of the fruit top of Gomortega keule (Mol.) Baill. A, frontal view of two styles, $\mathrm{x} 75$; B, the same, but from the upper, $\mathrm{x} 75$. 


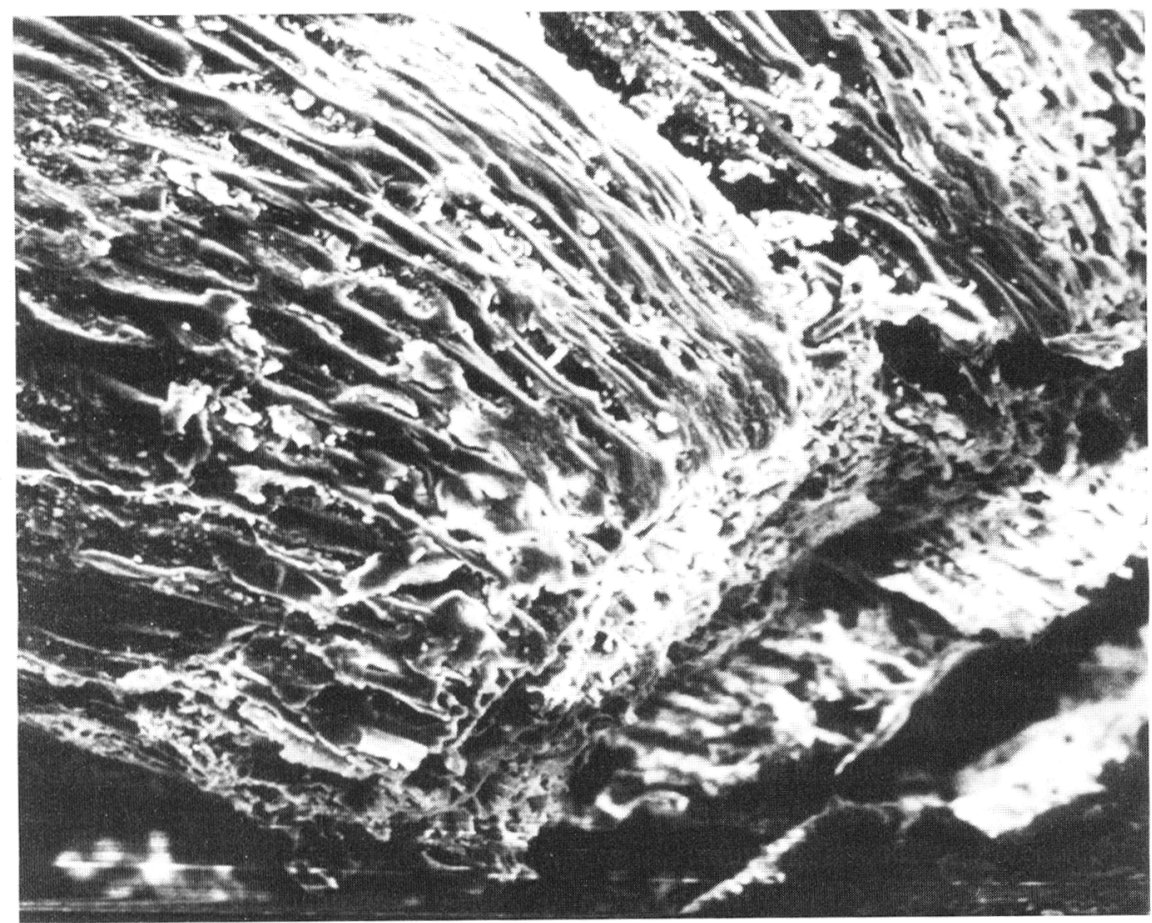

Figure 3. SEM micrograph of the striped surface of style, x 380 .

Silvicultura, Universidad de Chile (EIF). The collections were made by Rodolfo Gajardo on 23 February 1986 in Chile, Ramadillas, Altos de Tregualemu, $36^{\circ} 00^{\prime \prime} \mathrm{S}, 72^{\circ} 40^{\prime \prime} \mathrm{W}$ at $520 \mathrm{~m}$ elevation. The voucher specimens were housed in the Carpotheca of the National Institute of Carpology (Gaertnerian Institution), Moscow [NICAR]. Drawings were made with an assistance of PA-4 ${ }^{\circledast}$ camera lucida from microtome serial cross-sections 50 10 $\mu$ m thick, prepared by the usual paraffin method and stained with safranin-fast green (O'Brien \& McCully, 1981). Scanning Electron Microscope (SEM) observations were made with a HITACHI S-405 A at $15 \mathrm{kV}$ after sputtercoating with platinum-palladium.

\section{RESULTS}

\section{Fruit}

Mature fruits. The mature fruit (fig. 1) is yellow, obovoid or globose, $3.567 \mathrm{~cm}$ long and $3.5-5 \mathrm{~cm}$ wide, fleshy, indehiscent, drupaceous, (1-) 2-3-locular with $2(-3)$ styles (figs. 2, 3); originates from the (2-) 3 (-6)-merous coenocarpous inferior ovary (fig. 4). The fruit surface is rough due to the fruit shrivelling; fruit sculpturing is striped (figs. 5). The carpels are spirally arranged, some of them (mostly basal) abortive; the number of carpels is varying from 3-6 to more usual condition of fertile 2-3 (Reiche, 1896; 

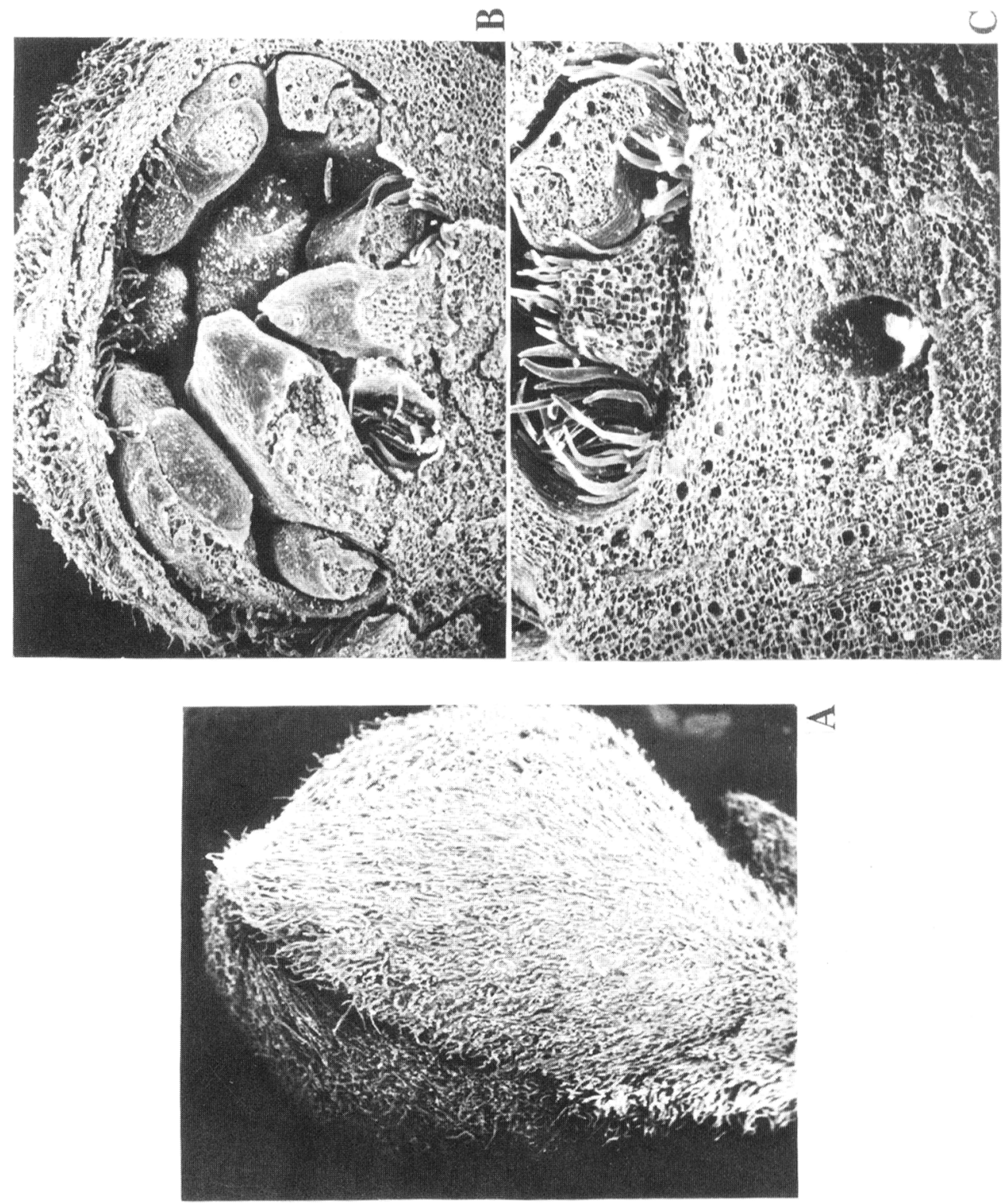

Figure 4. SEM micrographs of the developing ovary of Gomortega keule (Mol.) Baill. A, general view of the bud, x 30; B, upper part of the longitudinal dissection of the bud of Gomortega keule (Mol.) Baill., $x$ 75 ; $\mathrm{C}$, the same, but lower part, showing carpellary cavity, $x 75$. 

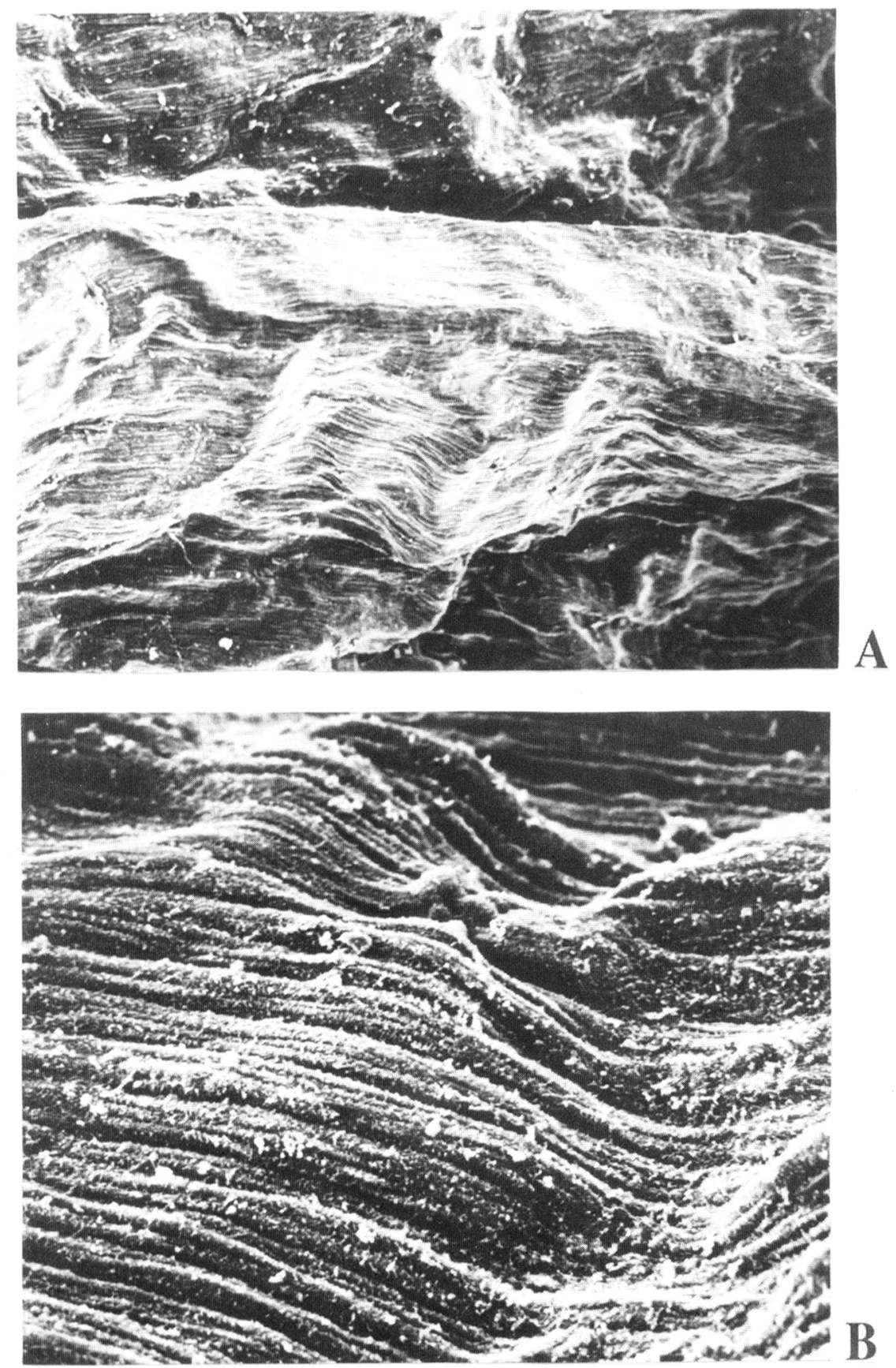

Figure 5. SEM micrographs of the fruit surface of Gomortega keule (Mol.) Baill. A, general rough sculpture, x 75; B, striped sculpturing, x 380 . 
Brizicky, 1959), thus giving the appearance of mostly 2-3-locular or even pseudomonomerous syncarpous fruit. Due to the lateral concrescence of carpels during anthesis the locules of the fruit are narrow, slit-like with marginal placentation of one (rarely two) ovules. The vascular skeleton of the fruit (fig. 6) is represented by numerous $(>30)$ vascular bundles in two circles, laying in the outermost fleshy part of pericarp, giving off numerous traces for spirally arranged (5-) $7-9$ tepals, 7-9 (-13) stamens and (1-) 3 (-4) staminodia, and independently originated distinct vascular supply to every carpel, which is consisted of one ventral trace and one dorsal, not extending upwards into the style ( $c f$. also Leinfellner, 1968).

Pericarp. This is differentiated into three to six layered exocarp, with up to 100 layers (c. $1.2-1.4 \mathrm{~cm}$ ) of mesocarp composing of two distinct zones (fleshy and stony), and a 4-5layered lignified fibrous endocarp (fig. 7-8). Such a sclerified mesendocarp-like construction of the whole pericarp is typical of drupaceous fruits (Garcin, 1891), and therefore the inferior fruit type of Gomortega should be redefined as a drupine according to a new system of fruit classification and terminology (Doweld \& Sorokina, 1997), but not a drupe (Reiche, 1896; Spjut, 1994).

The parenchymatous exocarp is composed of thin-walled cells filled with tannin-like dark substances (fig. 7 A). The mesocarp is differentiated into two distinct zones: the outer (fig. 7 B), remaining parenchymatous (c. 3-3.5 $\mathrm{mm}$ ), and massive sclerified inner one (c. $0.9-1.1 \mathrm{~cm}$ ) (fig. $7 \mathrm{C}$ ). The outermost parenchymatous part of mesocarp, adjacent to exocarp, is also characterized by the occurrence of $1-2$ zones of tannin-bearing cells, interrupted by the layers of colourless parenchyma (fig. $8 \mathrm{~A}$ ). In the thin-walled mesocarpic parenchyma there are numerous spherical secretory oil-cells with relatively thin, but sometimes lignified walls (fig. $8 \mathrm{C}$ ). In the zone of numerous vascular bundles there are one or sometimes two layers of lignified macrosclereids (fig. $7 \mathrm{C}$ ) with pitted walls. The inner part of mesocarp is represented by mostly radially elongated brachysclereids with heavily thickened and pitted walls (Figs 7 D, 8 B). The endocarp is represented by heavily thickened lignified and pitted fibres oriented parallelly to the axis of fruit (fig. $7 \mathrm{D}$ ).

\section{Seed}

Mature seeds. These are relatively large, $10-14 \mathrm{~mm}$ long, $6-8 \mathrm{~mm}$ wide and $4-6 \mathrm{~mm}$ thick, flattened, obcordate to ellipticlanceolate, slightly elongated, exarillate, brown (fig. 9 A). The hilum is black and large, basal. The raphe or antiraphe are not morphologically differentiated. The vascular skeleton is reduced and represents by small single vascular bundle terminating in chalaza under a large cup-shaped hypostase (fig. 9 B). There are no marks of pachychalaza reported by Igersheim \& Endress (1997). The mature seeds are albuminous, with a small straight dicotyledonous embryo (fig. 9 C).

Spermoderm. The seed coat (fig. 10) is formed from both integuments of the hemianatropous (suborthotropous) crassinucellate ovules. It is endotestalendotegmic. The seed sculpturing is rough, with numerous remnants of outer testal parenchyma (fig. 11).

The testa consists of 2-3 layers, one or two outermost of which are often obliterated in mature seeds, being composed of thin-walled parenchyma. The only mechanical layers is represented by tangentially elongate tracheidal thick-walled cells with numerous spiral or annular projections penetrating into the cell cavity ['Spiralzellenschicht' of Schleiden, 1839; tracheotesta].

The tegmen is composed of 3-4 layers of 

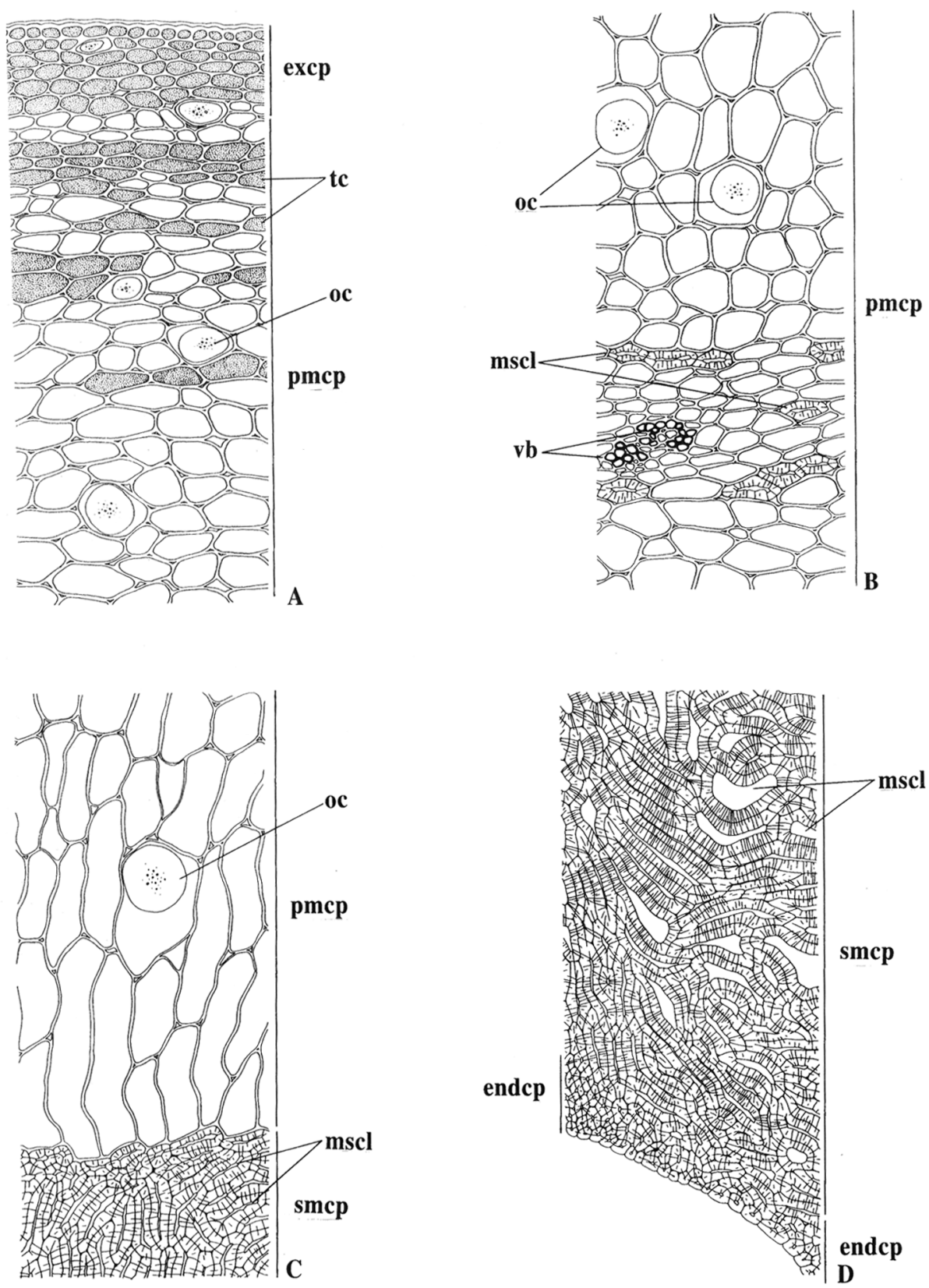

Figure 7. Cross-sections of the pericarp of Gomortega keule (Mol.) Baill., x 160. A, outermost part (incl. exocarp); B, mesocarpic parenchyma (outer parenchymatous part of mesocarp); C, zone of transition between parenchymatous and sclerenchymatous parts of mesocarp; D, innermost part of sclerified mesocarp and sclerendocarp. Abbreviations: excp, exocarp; pmcp, parenchymatous (outer) part of mesocarp; smcp, sclerified (inner) part of mesocarp; endcp, endocarp, oc, oil cells; tc, tanniniferous cells; mscl, macrosclereids, $\mathrm{vb}$, vascular bundles. 
thin-walled, only the innermost tanniniferous layer (endotegmen) of large, slightly tangentially elongate cells, does not crush in mature seeds. Other layers of parenchymatous tangentially elongated cells are collapsed, and only remnants are visible.

The remnants of the nucellus are represented by approx. one or two (rarely more) layers of large, thin-walled colourless cells, separated from the tegmen by a cuticular layer.

\section{DISCUSSION}

\section{Relationships with Canellaceae}

Metcalfe \& Chalk (1950) on the basis of xylem anatomy suggested that Canellaceae and Gomortegaceae are closely related. But as has been later stated by Stern (1955) and Gottwald (1977) the occurrence of homogeneous vascular rays and both apotracheal and paratracheal parenchyma in Canellaceae clearly distinguishes the latter taxon and places it into quite another structural group by xylem specialisation ['Myristical' of Gottwald, 1977]. Other characters of Canellaceae, such as monosulcate pollens (Walker, 1974 a, b; 1976), trilacunar nodal anatomy (Money, Bailey \& Swamy, 1950), pentamerous floral construction, including 4065 sepals and 205 carpellate superior paracarpous berry (Parameswaran, 1962), numerous seeds with ruminate endosperm, specialized exotestal seed coat construction (Canella P. Browne: Nemirovic-Dancenko, 1988) point out to the lack of any close phylogenetic relationships with Gomortegaceae having inaperturate pollens (Walker, 1974 a, b, 1976; Hesse \& Kubitzki, 1983), unilacunar nodal anatomy, mostly trimerous (although remaining indefinite) floral construction with numerous tepals and inferior ovary of drupaceous type (Buchheim, 1958; Brizicky, 1959), and quite distinct (in origin and morphogeny) endotestal- endotegmic spermoderm. Thus the idea of canellaceous affinity for Gomortega should be ruled out.

\section{Relationships with Chloranthaceae}

Hallier (1912) and later Money, Bailey \& Swamy (1950) and Swamy (1953) advocated an idea of the existence of close phylogenetic relationships between Gomortega and Chloranthaceae. In reality, Chloranthaceae possess some similar principal characters with Gomortegaceae, such as unilacunar nodes, secretary oil cells, primitive xylem structure, \pm similar trimerous floral construction [tripartite gynoecium in Hedyosmum Swartz. (Yamazaki, 1992)], albuminous seeds originating from \pm orthotropous ovules, and pollen grains inaperturate (Sarcandra Gardn.) to monocolpate (Ascarina Foerst.) and even polycolpate with a tendency towards again inaperturate (Hedyosmum, Chloranthus Swartz.). However, the suggested affinity appears to indicate only some distant relationships between these taxa. The occurrence of inferior ovary in Gomortega with a somewhat varying (indefinite ?) number of constituting carpels (from two to six), while in the Chloranthaceae the monocarpellary gynoecium is prevailing (Endress, 1987), the coenocarpous drupaceous type of fruit in contrast to mostly apocarpous baccate or rarely syncarpous assaraceous inferior (Hedyosmum) in Chloranthaceae, large, differentiated embryo of Gomortega vs. small, with slightly differentiated cotyledons in Chloranthaceae emphasize a certain distinctness of Gomortegaceae from Chloranthaceae. However, these differences do not upset the integrity of this possible single, though heterobathmic evolutionary line, because these families, being allied by a number of similarities in nodal and xylem anatomy as well as palynomorphology, display a specific similar tracheotestal, endotestal seed coat type, 

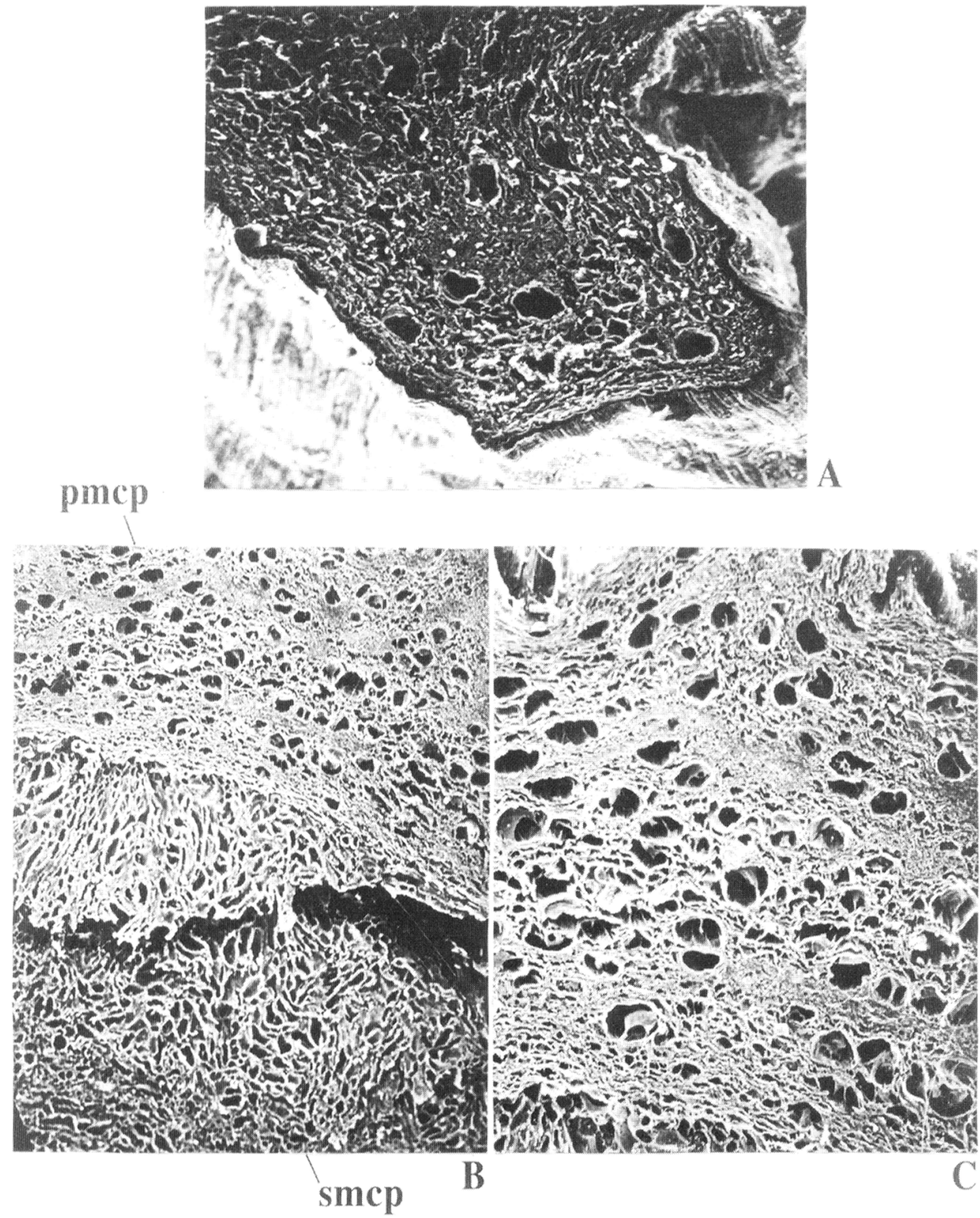

Figure 8. SEM micrographs of the pericarp tissues of Gomortega keule (Mol.) Baill. A, fleshy exomesocarpic parenchyma of the outermost part of pericarp, x 100; B, sclerified (smcp) and parenchymatous (pmcp) parts of mesocarp, x 150; C, mesocarpic parenchyma, x 200. 


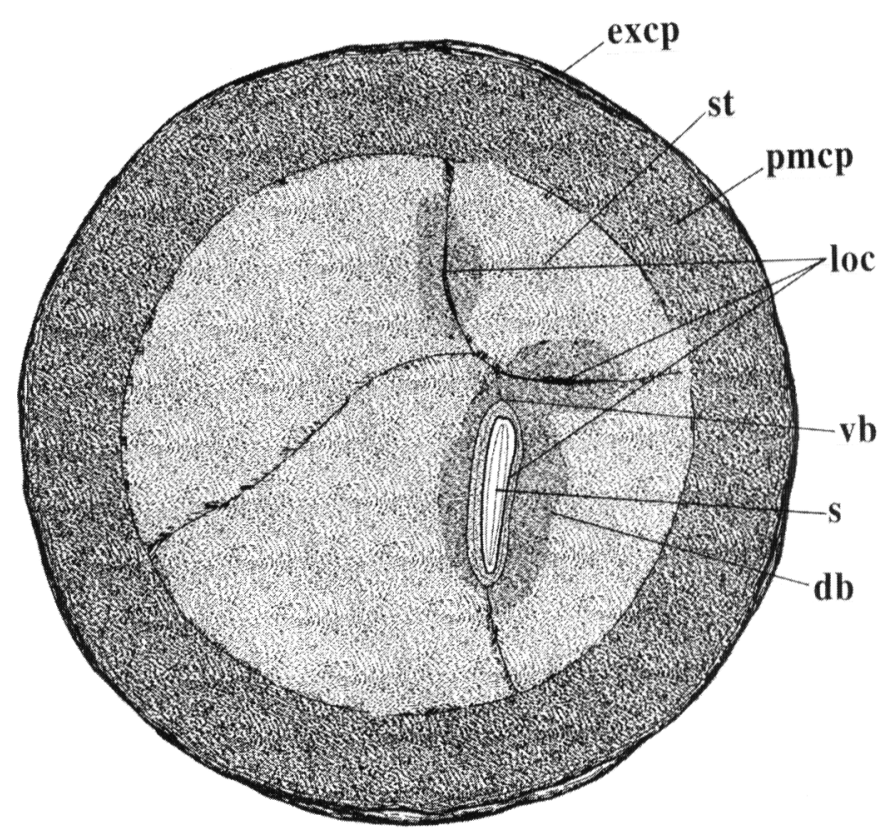

Figure 6. Cross-section of the fruit of Gomortega keule (Mol.) Baill., x 20. Abbreviations: excp, exocarp; $\mathrm{s}$, seeds; loc, locules; vb, ventral vascular bundles; db, dorsal vascular bundles; st, sclerified tissues of pericarp; pmcp, parenchymatus part of mesocarp.

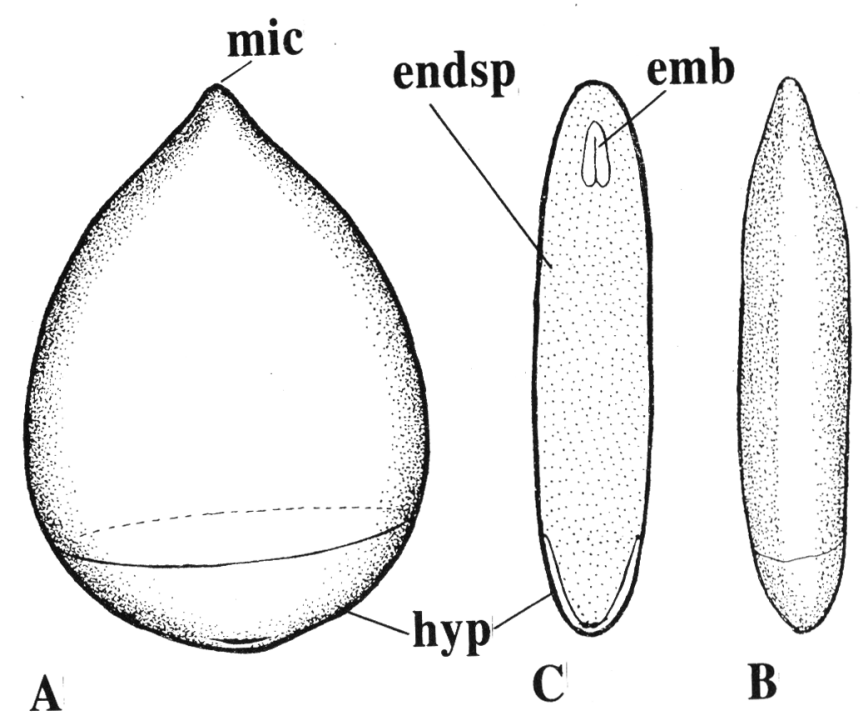

Figure 9. The seed of Gomortega keule (Mol.) Baill. A, general view, x 20; B, vascular skeleton and cupshaped hypostase, x 20; C, longitudinal section of the seed, x 20. Abbreviations: hyp, hypostase; endsp, endosperm; emb, embryo; mic, micropyle. 


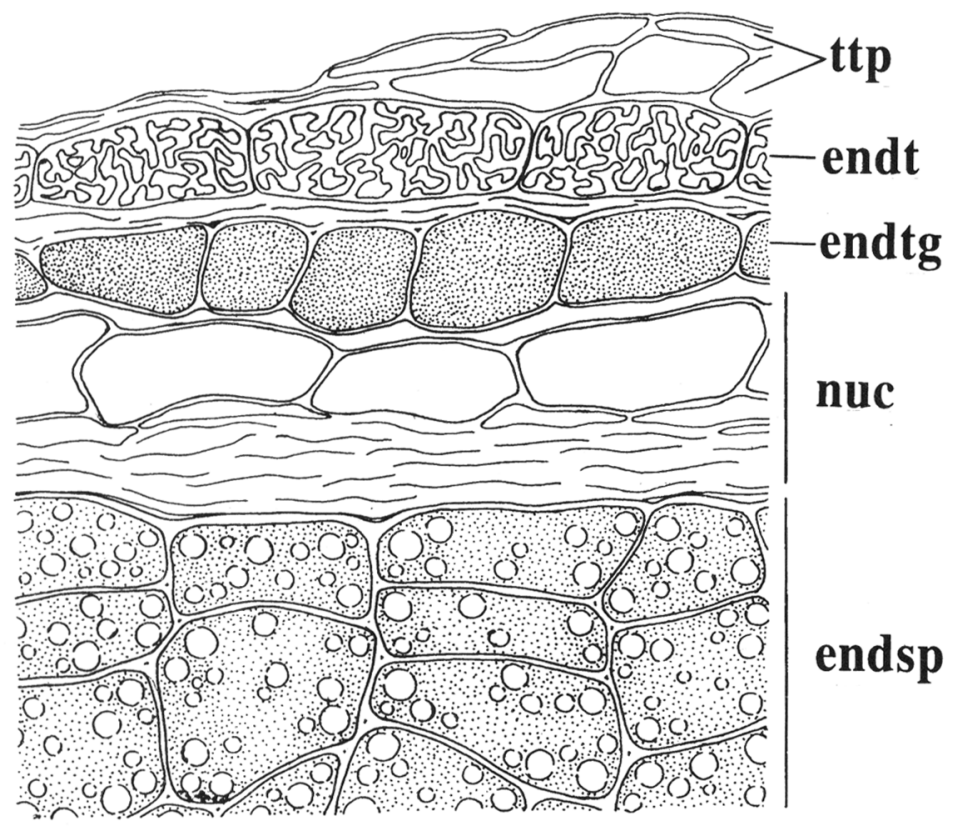

Figure 10. Cross-section of the seed coats of Gomortega keule (Mol.) Baill., x 800. Abbreviations: ttp, testal obliterated parenchyma; endt, endotesta; endtg, endotegmen; nuc, remnants of nucellus; endsp, endosperm.

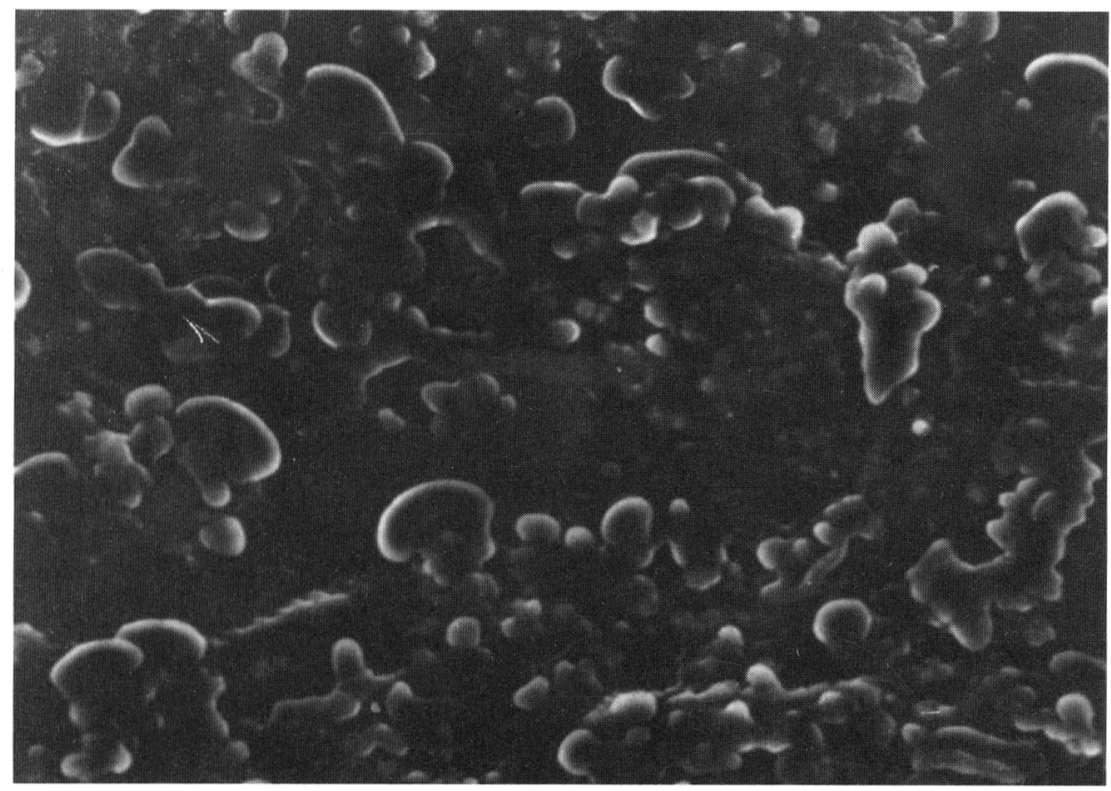

Figure 11. SEM micrograph of the seed surface of Gomortega keule (Mol.) Baill., showing obliterated testal parenchyma, x 380 . 
which is occurred in a very limited number of archaic families of angiosperms.

The family Chloranthaceae is diverse in seed coat types (Lodkina, 1988): the multilayered exotegmic type with a rudimentary thickened endotesta has been reported for Ascarina (Corner, 1976), the endotestal-exotegmic one for Chloranthus and Sarcandra (Vijayaraghavan, 1964; Lodkina, 1988), and highly advanced, unspecialized seed coat (parenchotestal-parenchotegmic) has been described in Hedyosmum (Edwards, 1920). The chloranthaceous endotesta, being representing by sclerified, tangentially elongate cells filled with 'internal cellulose processes as a fibrillar network' (Corner, 1976: 96) and crystals of calcium oxalate (appearing at the stage of progressive despecialization of sclerified structures), has all marks of the derivation from the tracheidal endotesta, similar to that of Gomortega. This principal key-character is indicative of a common ancestry for both taxa, though the appearance of unspecialized spermoderm in assare of Hedyosmum and gradual transference of the mechanical function from endotesta to tegmen with multiplicative sclerified exotegmen in series of Chloranthus-Sarcandra $\rightarrow$ Ascarina (endotestal-exotegmic $\rightarrow$ (endotestal-)exotegmic) confirm the distinctness of Gomortegaceae and Chloranthaceae. From the stand point of seed coat anatomy, these families definitely belong to the single, ancient and highly irradiated phylum of archaic Magnoliidae.

\section{Relationships with Lauraceae}

The recognition of the monocarpellary nature of the gynoecium in Lauraceae led Mez (1888) to exclude Gomortega from the family an reject any idea of close relationships between both taxa. Nevertheless, both families have a somewhat similar endotestal (tracheotestal) seed coat type, which is supplemented by additional similarities in unilacunar nodes, secretory oil cells, similar xylem structure (Stern, 1954, 1955), (trimerous floral plan, mostly bilocular anthers, inferior ovary (only in lauraceous Hypodaphnis zenkeri), inaperturate pollen grains, single pendulous ovule. But the monomery of the lauraceous gynoecium together with the differentiated two circles of six tepals, three stamens (or 32 in Cinnadenia) arranged in four circles, fruit (capseole) with only differentiated 1-layered endocarp from the inner epidermis of pericarp (not a drupe !), exalbuminous seeds with a greatly developed pachychalaza (e.g., up to \pm $2{ }_{3}$ of the seed in Laurus nobilis L.) call into question the phylogenetic closeness.

The seed coat of Lauraceae has a similar mechanical system of endotestal tracheidal layer, but with unspecialized and practically completely obliterated tegmen (Sastri, 1962; Corner, 1976). The number of layers in lauraceous testa (5-8 (-20)) and tegmen (2 4 ) is somewhat distinct from that of gomortegaceous ( $2-3$ and $3-4$ respectively); the enormous development of highly vascularized pachychalaza (Le Monnier, 1872; Corner, 1976) leads to the substitution of the usual bitegumentary system in most part of seed. These differences confirm phylogenetic distinctness of the Lauraceae from Gomortegaceae, and families seems represent quite different vectors in the evolution of similar distinctive endotestal seed coats, although they remain to be clearly affiliated with a single evolutionary line in Magnoliidae.

\section{Relationships with Monimiaceae}

The Monimiaceae s.l. comprising 6 subfamilies Hortonioideae (= Hortoniaceae), Atherospermatoideae (= Atherospermataceae), Siparunoideae (= Siparunaceae), Glossocalycoideae, Mollinedioideae, and Monimioideae (Philipson, 1987, 1988; Takhtajan, 1997), represent a quite unnatural, 
combined taxon with varying floral and fruit morphology; the delimitation of the family and splitting into several natural families (Pichon, 1948; Schodde, 1969, 1970; Smith, 1972) is ignored in recent systems of classification. The below positioned comparison of Gomortega with heterogeneous family emphasises the artificial circumscription of Monimiaceae s.l. Gomortegaceae, as practically all Monimiaceae s.l., are exstipulate with a decussate leaf arrangement, unilacunar nodes, and albuminous seeds with endotestal seed coats. But the combination of inferior coenocarpous ovary with a single ovule, spirally arranged stamens and carpels, primitive wood, valvular dehiscence of the anthers, relatively large embryo somewhat distances the family from the monimiaceous diverse alliance. Among all subfamilies of Monimiaceae s.l., Gomortega shows some similarities to Atherospermatoideae in having spirally arranged perianth, androecium and gynoecium, staminodial appendages (this feature is also shared with Hortonia Wight), carpels with a persistent styles, characteristic valvular dehiscence of anthers, Pcsf-type of sieve-element plastids (Behnke, 1988; much like also those of Calycanthaceae); but dramatically differs in having inferior ovary, although atherospermataceous genera, e.g. Doryphora Endl. and Dryadodaphne S. Moore, have a distinctive deeply concave, cupuliform receptacle, showing a prominent tendency toward epigyny, and thereby reducing a phylomorphogenetic gap between two taxa. The endotestal (tracheotestal) type of seed coat, typical for all Monimiaceae s.l. (except for parenchotestal Siparunoideae: Heilborn, 1931), almost with a rudimentary perichalazy, is indicative of a close phylogenetic relationship of Monimiaceae to Gomortega.

Although detailed descriptions of the monimiaceous pericarp are mostly missing or controversial (Foreman, 1984), the occurrence of the drupaceous differentiation of the whole pericarp in the drupeta of Hortonioideae (Corner, 1976), hypodrupeta of Siparunoideae (Heilborn, 1931) and Monimioideae (Corner, 1976) might be regarded as a connecting feature (nonetheless, one should be emphasized that monimiaceous taxa have apocarpous fruits in contrast to coenocarpous ones of Gomortega). The formation of the receptaculihiscent, mostly polymerous hypodrupeta in 'higher' Monimiaceae (Glossocalycoideae, Mollinedioideae, and some Monimioideae) represents itself a quite distinct vector in the evolution of fruits within Monimiaceae, starting from the archaic non-perigynous drupeta of Hortonia and some half-perigynous Atherospermatoideae. The latter taxa, as has been once proposed (Schodde, 1969, 1970), seems are rather most primitive 'splinters' of the massive endotestal evolutionary promonimiaceous line, and therefore, revealing close phylogenetic relationships with a distinct family Gomortegaceae, should be considered as distinct families having a common ancestry. The distinct familial rank of Gomortega showing close affinities to Atherospermatoideae and Hortonioideae precludes a possibility to consider them in the Monimiaceae s.l. Although Philipson (1987) thought that Gomortega might be united with Monimiaceae s.l. ("if its syncarpous inferior gynoecium is not considered sufficient to separate it decisively from the Monimiaceae'), this idea absolutely has not support in the structure of seed coats and fruits in general.

\section{Systematic position}

The traditional inclusion of the Gomortegaceae in Laurales (Cronquist, 1992; Thorne, 1992; Takhtajan, 1997) is fully supported by fruit and seed coat anatomy in particular. The drupaceous, though inferior and coenocarpous, fruits, albuminous seeds with endotestal-endotegmic spermoderm of Gomortega reveal a certain similarity with 
fruits and seeds of the Monimiaceae s.l., or more correctly, a group of the families of monimiaceous alliance. Although monimiaceous families are characterized by apocarpous fruits, the trend towards gomortegaceous epigyny is evident in the formation of specialized perigynous drupeta (hypodrupeta), the indehiscent and fewcarpelled forms of which with indefinite number of carpels have a principal construction like those in Gomortega. The available carpological and phermatological data on Gomortegaceae, together with data on palynomorphology (Agababian, 1973; Walker, 1974 a, b, 1976; Hesse \& Kubitzki, 1983), chromosome analysis (Goldblatt, 1976), and morphology of sieve-element plastids (Behnke, 1988) question the unity of Monimiaceae s.l. (sensu Philipson, 1987, 1988), requiring to split the heterogeneous family into series of smaller natural groups in which characters are easily grasped. In this case, the relationship of Gomortega is definitely with the family Atherospermataceae, having a distinctive staminodial appendages and valvular dehiscence of anthers, somewhat similar pollen morphology (Sampson \& Foreman, 1988), karyotype $n=22$ (Goldblatt, 1976), drupaceous differentiation of pericarp, endotestal seed coat construction, copious endosperm (Sampson, 1969 a, b), similar xylem (Garratt, 1934; Stern, 1955), and nodal anatomy (Money, Bailey \& Swamy, 1950), specific Pcsf-type of sieveelement plastids (Behnke, 1988). With the addition of more data on carpology and phermatology of Atherospermataceae and other monimiaceous taxa, the close relationships and common origins of Gomortega and Atherospermataceae would be more evident.

Amongst Magnoliidae, the similar Pcsftype of sieve-element plastids Gomortega shares also with Calycanthaceae representing a single order Calycanthales (Takhtajan, 1997). This circumstance emphasises the validity, in my opinion, of the argued splitting of the
Monimiaceae s.l. Nevertheless, Calycanthaceae are more remote phylogenetically from Gomortegaceae than Atherospermataceae, because they have more advanced structure of markedly perigynous (Baccarini, 1885; Tiagi, 1963) fruits (hypassareta with sclerified exo- and endocarp only: Lignier, 1892), exalbuminous seeds, though also endotestal and rudimentary perichalazal (? pachychalazal: Brofferio, 1930). The large embryo with massive convolute cotyledons also points to a high specialisation of Calycanthaceae. Using fruit and seed coat structure of Calycanthaceae, it is impossible to support the close phylogenetic proximity of Gomortega to this family which, perhaps, represents a relic and early diverging side-branch to monimiaceous ancestry. Therefore, the occurrence of the similar type of sieve-elements plastids in Gomortega and Calycanthaceae are not indicative of very close phylogenetic relationships.

The same remote, though not so far, phylogenetic relationships Gomortega shows to eulauralean families, Lauraceae and Hernandiaceae (incl. Gyrocarpaceae) (Takhtajan, 1997), the unicarpellate gynoecium of which precludes any possibility to affiliate Gomortegaceae with this group of families. The endotestal seed coat construction in both families (except for parenchotestal Hernandioideaeó Hernandiaceae) may serve as a connecting link between monimiaceous and lauraceous phyla (Mohana Rao, 1986). However, within eulauraleans there are: progressive development of pachychalaza (Lauraceae), epigynous fruit construction on the basis of unicarpellate gynoecium (Hypodaphnis Stapf in Lauraceae and all Hernandiaceae), more specialized pericarp differentiation (i.e. formation of the assaraceous inferior pericarp in HernandioideaeóHernandiaceae together with preservation of the initial capsular structure of the whole pericarp with a single-layered 
sclerified endocarp typical for apocarpous Lauraceae), exalbuminous seeds with massive embryos having labyrinth, folded or spirally twisted large cotyledons. All these characters are markers of the great advance of Lauraceae and Hernandiaceae in comparison to archaic Gomortegaceae, connecting it with more primitive families of monimiaceous alliance.

\begin{abstract}
ACKNOWLEDGEMENTS. I gratefully acknowledge the kind assistance of Dr. María Teresa Serra V., Herbario, Departamento de Silvicultura, Universidad de Chile, Santiago de Chile (EIF), for providing herbarium materials of Gomortega. Special thanks go to Mrs Francesca B. Yakovleva for helpful assistance with the SEM studies. Sincere thanks are extended to Ms Natalie A. Shevyryova for excellent morphological drawings used in paper. I am also obliged to the Staff of the Library of the Moscow Society of Naturalists (N. Bobrinsky, A. Dem'yanenko, L. Kuznetsova, and I. Gracheva) for providing some old botanical literature. This research was supported in part by the Karporamal Carporama Project and Systema Spermatophytorum Project of the National Institute of Carpology (Gaertnerian Institution), Moscow, NICAR.
\end{abstract}

\section{REFERENCES}

AGABABIAN, V.Sh. -1973-Pollens of the primitive angiosperms. Erevan: Izdatelstvo Akademii Nauk Armjanskoj SSR. [In Russian].

BACCARINI, P. -1885- Osservazioni anatomiche sopra alcuni ricettacoli fiorali. Annuar. R. Istit. Bot. Roma 1(1884): 66-88.

BAILLON, H. -1867/1869- Histoire des Plantes. Vol. 1. Renonculacées, Dilléniacées, Magnoliacées, Anonacées, Monimiacées, Rosacées. Librairie Hachette et $\mathrm{C}^{\mathrm{ic}}$, Paris.

BEHNKE, H.D. -198- Sieve-element plastids, phloem protein, and evolution of flowering plants: III. Magnoliidae. Taxon 37: 699-732.

BENTHAM, G. \& J.D. HOOKER -1883-Genera plantarum ad exemplaria imprimis in Herbarii Kewensibus servata definita. Vol. 3. Monochlamydearum, Gymnospermearum et monocotyledonum ordines LXXIII. Londini: L. Reeve \& Co.
BESSEY, C.E. -1915- The phylogenetic taxonomy of flowering plants. Ann. Missouri Bot. Gard. 2: 109-164.

BRIZICKY, G.K. -1959- Variability in the floral parts of Gomortega (Gomortegaceae). Willdenowia 2: 200-207.

BROFFERIO, I. - 1930- Osservazioni sullo sviluppo della Calycanthaceae. Ann. Bot. (Roma) 18: 387-394.

BUCHHEIM, G. -1958- Bemerkungen zum Andrözeum der Gomortegaceae. Willdenowia 2: $27-31$.

CORNER, E.J.H. -1976- The Seeds of Dicotyledons. Vols 1, 2. Cambridge University Press, Cambridge.

CRONQUIST, A. -1992- An integrated system of classification of flowering plants. 2nd ed. Columbia University Press, New York.

DAHLGREN, G. -1989- An updated angiosperm classification. Bot. J. Linn. Soc. 100: 197-203.

DOWELD, A.B. \& E.A. SOROKINA -1997- A terminology of the principal types of the fruits in flowering plants. Naucn.-Tekhn. Terminol. 1997(1): 33-39. [In Russian].

EDWARDS, E.S. -1920- Flower and seed of Hedyosmum nutans. Bot. Gaz. 70: 409-424.

ENDLICHER, S. -1836/1840- Genera plantarum secundum ordines naturales disposita. Apud F. Beck Universitatis Bibliopolam, Vindobonae.

ENDRESS, P.K. -1987- The Chloranthaceae: reproductive structures and systematic position. Bot. Jahrb. Syst. 109: 153-226.

ENDRESS, P.K. \& A. IGERSHEIM -1997Gynoecium diversity and systematics of the Laurales. Bot. J. Linn. Soc. 125: 93-168.

ENGLER, A. -1919-Syllabus der Pflanzenfamilien. 8 ed. Gebrüder Borntraeger, Berlin.

ESPINOSA BUSTOS, M.R. -1948- Estudios botánicos. 2. Nomenclatura del Queule. Bol. Mus. Nac. Hist. Nat. (Santiago de Chile) 24: 70-79.

FEDOTOVA, T.A. -1988- Gomortegaceae. In Anatomia Seminum Comparativa. Vol. 2. Edited by A.L. Takhtajan. Nauka, Leningrad. pp. 68. [In Russian].

GARCIN, A.G. -1891-Contribution à l'Ètude des pèricarpes charnus. Du noyau des drupes. Histologie et histogènèse. Ann. Soc. Bot. Lyon 17(1890): 27-39.

GARRATT, G.A. -1934- Systematic anatomy of the 
woods of the Monimiaceae. Trop. Woods 39: $18-44$.

GOLDBLATT, P. - 1976- Chromosome number in Gomortega keule. Ann. Missouri Bot. Gard. 63: 207-208.

GOTTWALD, H. -1977- The anatomy of the secondary xylem and the classification of ancient dicotyledons. Pl. Syst. Evol. Suppl. 1: 111-121.

GUNCKEL, H. -1972- Plantas chilenas descritas como nuevas por Juan Ignacio Molina y sus concordancias con la nomenclatura bot.nica actual. Noticiar. Mens. Mus. Nac. Hist. Nat. (Santiago de Chile) 197: 3-11.

HALLIER, H. -1912- Lorigine et le système phylétique des Angiospermes exposés à laide de leur arbre généalogique. Arch. Néerl. Sci. Exact. Nat. Sér. 3B (Sci. Nat.) 1: 146-234.

HEILBORN, O. -1931- Studies on the taxonomy, geographical distribution and embryology of the genus Siparuna Aubl. Svensk Bot. Tidskr. 25: 202-228.

HESSE, M. \& K. KUBITZKI -1983- The sporoderm ultrastructure in Persea, Nectandra, Hernandia, Gomortega and some other lauralean genera. Pl. Syst. Evol. 141: 299-311.

HUTCHINSON, J. -1926- The families of flowering plants. I. Dicotyledons. Arranged according to a new system based on their probable phylogeny. MacMillan \& Co, London.

JOHNSTON, I.M. -1924- Taxonomic records concerning american spermatophytes. 4 . On the validity of Molina's scientific names. Contr. Gray Herbarium 70: 90-92.

LE MONNIER, G. -1872- Recherches sur la nervation de la graine. Ann. Sci. Nat. Sér. 6, Bot. 16: 233-305.

LEINFELLNER, W. -1968- Über die Karpelle verschiedener Magnoliales. VI. Gomortega keule (Gomortegaceae). Öster. Bot. Zeitschr. 115: 113-119.

LIGNIER, O. -1892- La graine et le fruit des Calycanthacées. Bull. Soc. Linn. Normandie. Sér. 4 5(1891): 19-33.

LINDLEY, J. -1853- The Vegetable Kingdom; or, The structure, classification and uses of plants, illustrated upon the natural system. 3rd ed. Bradbury \& Evans, London.

LINNÉ, C. -1753- Species plantarum, exhibentes plantas rite cognitas, ad genera relatas, cum differentiis specificis, nominibus trivialibus, synonymis selectis, locis natalibus, secundum systema sexuale digestas. T. 1. Laurentii Salvii, Holmix.

LODKINA, M.M. -1988- Chloranthaceae. In Anatomia Seminum Comparativa. Vol.2. Edited by A.L. Takhtajan. Nauka, Leningrad. pp. 89 92. [In Russian].

METCALFE, C.R. \& L. CHALK -1950- Anatomy of the Dicotyledons. Leaves, stem, and wood in relation to taxonomy with notes on economic uses. Vols 1, 2. Clarendon Press, Oxford.

MEZ, C. -1888- Lauraceae Americanae monographice descriptae. Jahrb. K. Bot. Gart. Mus. Berlin 5: 1-556.

MOHANA RAO, P.R. -1986- Seed and fruit anatomy in Gyrocarpus americanus with a discussion of the affinities of Hernandiaceae. Israel J. Bot. 35: $133-152$.

MOLINA, J.I. -1782- Saggio sulla storia naturale del Chili. Stamperio di T. d'Aquino, Bologna.

MOLINA, J.I. -1810- Saggio sulla storia naturale del Chili. $2^{\text {nd }}$ ed. Tipografia de' Fratelli Masi e Comp., Bologna.

MONEY, L.L., I.W. BAILEY \& B.G.L. SWAMY 1950- The morphology and relationships of the Monimiaceae. J. Arnold Arbor. 31: 372-404.

NEMIROVIC-DANCENKO, E.N. -1988Canellaceae. In Anatomia Seminum Comparativa. Vol. 2. Edited by A.L. Takhtajan. Nauka, Leningrad. pp. 31-32. [In Russian].

O'BRIEN, T.P. \& M.E. MCCULLY -1981- The Study of Plant Structure: Principles and selected Methods. Termarcarphi and Pty. Ltd., Melbourne.

PARAMESWARAN, N. -1962- Floral morphology and embryology in some taxa of the Caneliaceae. Proc. Indian Acad. Sci. Sect. B 55: 167-188.

PERSOON, C.H. -1805- Synopsis plantarum seu Enchiridium botanicum, complectens enumerationem systematicam specierum hucusque cognitarum. Pt. 1. Apud C. F. Cramerum, Parisiis Lutetiorum; Apud J. G. Cottam, Tubingae.

PHILIPPI, R.A. -1864/1865- Plantarum novarum Chilensium centuriæ, inclusis quibusdam Mendocinis et Patagonicis. Linna'a 33: 1-308.

PHILIPPI, R.A. -1865- Descripción de algunas plantas nuevas chilenas. Anal. Univ. Chile 26: 638-650.

PHILIPPI, R.A. -1868- Über die Adenostemum nitidum, Pers. Bot. Zeit. 26: 217-221. 
PHILIPSON, W.R. -1987- A classification of the Monimiaceae. Nordic J. Bot. 7: 25-29.

PHILIPSON, W.R. -1988- A classification of the Monimiaceae: an additional note. Nordic J. Bot. 8: 24 .

PICHON, P. -1948- Les Monimiacées: famille hétérogène. Bull. Mus. Nat. d'Hist. Nat. Paris, Sèr. 2 20: 383-384.

REICHE, K. -1896-Zur Kenntniss von Gomortega nitida R. et Pav. Ber. Deutsch. Bot. Ges. 14: 225-233.

RUIZ LÓPEZ, H. \& J. PAVÓN -1794- Flora peruvianae, et chilensis prodromus, sive, Novorum generum plantarum peruvianarum, et chilensium descriptiones, et icones. Descripciones y láminas de los nuevos géneros de plantas de la flora del Perú y Chile. Imp. de Sancha, Madrid.

SAMPSON, F.B. -1969a- Studies on the Monimiaceae. II. Floral morphology of Laurelia novae-zelandiae A. Cunn. (subfamily Atherospermatoideae). New Zealand J. Bot. 7: 214-240.

SAMPSON, F.B. $-1969 b$ - Studies on the Monimiaceae. III. Gametophyte development of Laurelia novae-zelandiae A. Cunn. (subfamily Atherospermatoideae). Austral. J. Bot. 17: 425-439.

SAMPSON, F.B. \& FOREMAN, D.B. -1988- Pollen morphology of Atherosperma, Daphnandra, and Doryphora (Atherospermataceae [Monimiaceae]). Grana 27: 17-25.

SASTRI, R.L.N. -1962- Studies in Lauraceae. III. Embryology of Cassytha. Bot. Gaz. 123: 197-206.

SCHLEIDEN, M.J. - 1839- Botanische Notizen, 9. <ber die Spiralzellenschicht in der Frucht der Laurineen. Arch. Naturgesch. Jahrg. 5 1:288-290.

SCHODDE, R. -1969- A monograph of the family Atherospermataceae $R$. Br. Vols 1, 2. Thesis, University of Adelaide.

SCHODDE, R. -1970- Two new suprageneric taxa in the Monimiaceae alliance. Taxon 19: 324-328.

SMITH, A.C. -1972- An appraisal of the orders and families of primitive extant angiosperms. $J$. Indian Bot. Soc. 50A: 215-226.

SPJUT, R.W. -1994- A systematic treatment of fruit types. Mem. New York Bot. Gard. 70: 1-182.

STERN, W.L. -1954- Comparative anatomy of xylem and phylogeny of Lauraceae. Trop. Woods 100: 1-73
STERN, W.L. -1955- Xylem anatomy and relationships of Gomortegaceae. Amer. J. Bot. 42: 874-885.

SWAMY, B.G.L. -1953- The morphology and relationships of Chloranthaceae. J. Arnold Arbor. 34: 375-411.

TAKHTAJAN, A.L. -1997-Diversity and classification of flowering plants. Columbia University Press, New York.

THORNE, R.F. - 1992-Classification and geography of the flowering plants. Bot. Rev. (Lancaster) 58: 225-348.

TIAGI, Y.D. -1963- Vascular anatomy of the flower of certain species of the Calycanthaceae. Proc. Indian Acad. Sci. Sect. B, Biol. Sci. 58: 224234.

VIJAYARAGHAVAN, M.R. -1964- Morphology and embryology of a vesselless dicotyledon Sarcandra irvingbaileyi Swamy, and systematic position of Chloranthaceae. Phytomorphology 14: 429-441.

WALKER, J.W. - 1974a- Evolution of exine structure in the pollen of primitive angiosperms. Amer. $J$. Bot. 61: 891-902.

WALKER, J.W. -1974 $b$-Aperture evolution in the pollen of primitive angiosperms. Amer. J. Bot. 61: 1112-1137.

WALKER, J.W. -1976-Comparative pollen morphology and phylogeny of the ranalean complex. In Origin and early evolution of Angiosperms. Edited by C.B. Beck. Columbia University Press, New York. pp. 241-295.

YAMAZAKI, T. -1992- Floral morphology of Hedyosmum orientale Merr. et Chun (Chloranthaceae) and phylogenetic significance of its perianth. J. Jap. Bot. 67: 257-269.

Aceptado para su publicación en junio de 2001

Author's address. National Institute of Carpology (Gaertnerian Institution), PO Box 72, RUS-119517, Moscow, Russian Federation; e-mail: nicar@aha.ru 